\title{
Determinants of biogas technology adoption in southern Ethiopia
}

\author{
Lemma Shallo ${ }^{1}$, Mitiku Ayele ${ }^{2}$ and Getachew Sime ${ }^{3,4^{*}}$ (i)
}

\begin{abstract}
Background: Renewable energies such as biogas are considered as clean sources of energy that minimize environmental impacts and are sustainable with regard to current and future economic and social needs. Biogas offers an attractive option for replacing the unsustainable usage of traditional energy sources such as firewood, cow dung, and charcoal in developing countries. In Ethiopia, these energy sources have been in decline. To address these challenges, mainly in rural areas, biogas technology has been domesticated since 2009, as seen in the National Program. The purpose of this study is thus to examine factors that influence households' decisions of adopting biogas technology in rural areas in southern Ethiopia.
\end{abstract}

Methods: A sample of 268 households with 134 biogas adopters and 134 non-adopters were surveyed using simple random and purposive sampling techniques, respectively. The data were collected through individual interviews of households using a semistructured questionnaire. Descriptive statistics and a binary logistic regression model were used for the data analysis. The binary logistic regression model was applied to identify determinant factors affecting the adoption of biogas technology.

Results: The results of the study indicated that biogas adopter and non-adopter households had significant mean differences in education level, cattle size, household income, farmland size, number of planted trees as well as the distance to water sources, market places, and firewood sources. Level of education, level of income, access to credit, distance to firewood sources, and access to electronic media had a significantly positive influence on the adoption of biogas technology. Conversely, distance to water sources and access to electricity had a significantly negative influence on the adoption of biogas technology.

Conclusions: Biogas technology mostly appears in privileged households having a better socioeconomic status and other resource endowments. The beneficiaries are thus households that can afford the higher initial investment costs for bio-digester installation, maintenance services and purchasing bio-digester spare parts; as well as households that have access to credit facilities, water sources for adequate water supply, markets for purchasing spare parts and electronic media for information, and also households residing far away from firewood sources.

Keywords: Biogas energy, Technology adoption, Binary logistic regression, Ethiopia

\section{Background}

Energy plays a central role in the national development process as a domestic necessity and a major factor of production [1]. Its contribution is holistic because it serves social, economic, political, and environmental aspects of development including access to healthcare, water, agricultural and industrial productivity, education, and other vital services [2]. Typically, energy is based on two

\footnotetext{
*Correspondence: abigiag@yahoo.com

${ }^{3}$ Department of Biology, College of Natural Sciences, Hawassa University, PO Box 05, Hawassa, Ethiopia

${ }^{4}$ Department of Plant Sciences (IPV), Norwegian University of Life Sciences (NMBU), Ås, Norway

Full list of author information is available at the end of the article
}

sources: renewable or non-renewable. Due to the depletion of non-renewable fossil energy sources, in recent years, there has been a growing interest in renewable biomass-based energies [3] which have motivated widespread research to be carried out particularly in the field of biogas energy. Biogas energy is developed in domestic bio-digesters that convert animal dung and human excrement into biogas through anaerobic digestion. Biogas is a combustible gas that is mainly composed of methane (60$70 \%)$ and carbon dioxide (30-40\%). Anaerobic digestion consists of several interdependent, complex, sequential, and parallel biological reactions that occur in the absence of oxygen. During this process, the products from one 
group of microorganisms serve as food for the next, resulting in the transformation of biomass, mainly in a mixture of methane and carbon dioxide [4], which are major constituents of biogas.

There are three major types of digesters, which have been commonly used in developing countries: the fixed dome digester (Chinese): the floating drum digester (Indian), and the bag digester (Taiwan) $[1,5]$. In Ethiopia, the National Biogas Program (NBP) has domesticated small size (4-10 $\mathrm{m}^{3}$ ) Chinese fixed dome-shape digesters. Such bio-digesters are usually constructed underground and, thus, are suitable for rural households and less vulnerable to damage $[6,7]$.

Adoption of technology is a process that ranges from hearing about the technology, gathering information about the technology, developing interest, and evaluating attributes of the technology for making the eventual decision of either taking up or rejecting the technology [8]. In this cross-sectional study, however, the major focus is not on the entire process of adoption of biogas technology, but on the underlying and proximate factors influencing a households' final decision of either using or rejecting biogas technology. It is a cost-effective and an eco-friendly technology [9] which enhances energy security and reduces environmental pollution and greenhouse gas emissions [10]. Although its benefit is enormous, the rate of adoption of biogas technology is very limited and the vast majority of the population in developing countries still depends on traditional energy systems. In Sub-Saharan Africa (SSA), biomass mainly in the form of wood-fuel and charcoal are the dominant energy source used [1]. In Ethiopia, about $81.4 \%$ of households use firewood, $11.5 \%$ use leaves and dung cakes, and $2.4 \%$ use kerosene for cooking [2]. The Ethiopian Rural Energy Development and Promotion Center (EREDPC) and the SNV Netherlands Development Organization reported that traditional fuels provide $99.8 \%$ of the total (rural and urban) domestic energy supply, with $88 \%$ derived from woody biomass, $10 \%$ of crop residues, $1 \%$ of dung, and $0.8 \%$ of charcoal [6]. However, the depletion of these energy sources has urged the Ethiopian government, nongovernment organizations, and international actors to look for alternative renewable energy sources. Growing environmental concerns, energy security needs, and the increasing price of fossil fuels contribute to this necessity. In the case of poor economies such as in Ethiopia, quality of life and energy consumption are tidily conjoined [3].

Therefore, witnessing the increasing interest in renewable energy and the technical potential, Ethiopia launched a National Biogas Program (NBP) in 2008. The first phase of the program ran from 2009 to 2013 and the second phase from 2014 to 2017 [6]. In the first phase, the country was able to build 8063 (57.6\%) out of the 14,000 domestic bio-digesters originally intended to be constructed in the first period [11].
In connection to this, the Sodo Gurage district (study area) is one of 21 districts in the Southern Nation Nationalities and Peoples Regional State (SNNPRS) that has implemented the biogas program. Although the National Biogas Program (NBP) started its first phase in 2009, the district joined the program in the year 2011. As per the Regional Biogas Program Coordination Unit (RBPRU), out of 206 targeted bio-digesters installations, only 186 biodigesters were installed in the first phase of the NBP [12]. In the second phase, only $19.4 \%$ of family-sized biodigesters were installed at the time of pursuing this study. The trend shows that the installation and, hence the rate of adoption of the technology has gradually been decreasing. Therefore, it is mandatory for further domestication of the technology among rural communities to improve energy security, to reduce dependence on currently depleting firewood for energy generation, to decrease the deforestation rate as well as usage of chemical fertilizer and to mitigate climate change and rainfall variability. In line with this, the assessment and further study of factors influencing the adoption of biogas technology are becoming very important.

Several research studies were conducted encompassing factors that affect the transfer of household-level biogas technology to a global level. A study conducted in a few Asian countries (Nepal, Cambodia, Bangladesh, Vietnam, and India) showed that insufficient national policies, lack of credit and subsidy facilities, and lack of active involvement of the private sector were among the major factors determining national biogas promotion [13]. In SSA, inefficiencies in quality control and standardization, integrated use of agricultural residues and bio-slurries, as well as mobilization of domestic and foreign funds and the use of readily available funds were the major socioeconomic and institutional obstacles to the adoption of biogas technology [4]. Amigun et al. have reported in [1] that high initial investment costs are a key challenge to biogas technology adoption among the rural poor in Africa, despite political, sociocultural, financial, informational, institutional, technical, and training constraints. Parawira has mentioned in [14] that research studies with regard to capital costs and operating costs of biogas production might generate revenues that can be tolerated, whereas studies with regard to bio-digester size, type of feedstock, and other location-specific variables are mandatory for biogas technology adoption. Moreover, effective incentives in the form of taxes and financial subsidies and public outreach and education are key factors to weaken the socioeconomic and cultural barriers to markedly increase the adoption of biogas technology in Africa.

So far, there have been only a few studies aimed at identifying factors affecting the adoption of biogas technology in rural areas in different countries [15-18]. In 
Bangladesh, years of education, income level, number of cattle, and gender of the household head had a significant influence on the decision of biogas technology adoption [17]. In China, socioeconomic factors, including household size, age of the household head, and household income level were the major factors influencing a household's decisions in adopting biogas technology [18]. Mwirigi et al. [15] have investigated the socioeconomic factors that influence the adoption and the sustainable adoption of biogas technology in the Nakuru district in Kenya. This study shows that socioeconomic factors such as the education level of the household head, family income, farm size, and cost of the dairy cattle and farming system have significantly influenced the decision to adopt biogas technology. The gender of the head of the household, household income, number of cattle owned, household size, educational status of a household, cost of traditional fuels, distance to firewood and water sources and land size owned are among the key factors influencing biogas technology adoption in Uganda [16]. In Africa, successful development and management of biogas technology require not only technical expertise but also serious attention to economic, political and social issues, as well as human behavior [14].

As far as related studies in Ethiopia are concerned, only a few deals with the identification of factors that influence the adoption of biogas technology. Eshete et al. [19] carried out a feasibility study for the NBP and have identified income level, access to water, access to infrastructure, and gender imbalance as the main constraints that affect the adoption of biogas technology in rural Ethiopia. Mengistu et al. [20] have found some additional factors affecting the adoption of biogas technology such as education level, heads of cattle, access to credit, distance to firewood sources and the number of planted trees. Berhe et al. [21] have identified more factors, including working age, gender, access to electricity, and livestock mobility that influence households' choice of biogas technology. However, none of the previous studies has considered the factors such as individuals' perception of the use and management of biogas and bio-slurries, and access to media as among those that might influence the adoption of biogas technology or not. Factors that influence the adoption of biogas technology, which is the major focus of the study, have rarely been investigated in empirical studies for southern Ethiopia, and in particular for the study district.

\section{Materials and methods}

\section{Theoretical framework}

The theoretical framework is based on two commonly used energy transition theories, which are employed to analyze household energy demand in relation to the adoption of biogas technology. These are the "energy ladder" model and the "fuel stacking" or "multiple fuel use" approach. The energy ladder theory has been utilized to illustrate the gradual transition of households from the use of traditional biomass fuels to modern fuels. It makes an analogy between household fuel choices and a ladder [22]. Accordingly, the theory views household fuel choices as a progression that corresponds to increases in income along with a hierarchical order from "inferior" traditional biomass energy resources to transitional fuels and eventually "superior" modern commercial fuels. The energy ladder approach perceives a continuous monotonic fuel substitution process as income increases [23].

Recently, many studies have theorized household energy choices, alternatively from a viewpoint of "fuel stacking" or "multiple fuel use." The fuel-stacking concept predicts that households will combine different energy sources for different end-uses and that fuel choices are not mutually exclusive because households can use any combination of fuels at a given point in time. In addition to income, the fuel-stacking concept asserts that there are numerous factors that determine household fuel choice decisions. Both the energy-ladder and fuel-stacking concepts emphasize consumer demand theory and are more complementary rather than substitute approaches [3, 24]. It illustrates how household livelihoods are linked to the adoption of modern energy, such as biogas technology.

\section{Description of the study area}

The Gurage zone is located in the southwestern and northern part of the Southern Nations, Nationalities and Peoples Regional State (SNNPRS) (Fig. 1). It is bordered by the Siltie zone to the southeast, and the Hadia zone and Yem special district to the south and southwest, respectively. The northern, western and eastern parts share borders with the Oromia Regional State. According to the Central Statistical Agency (CSA) and its population projection, the total population of the zone is estimated to be 1,597,360 in 2016 (48.5\% male and 51.5\% female). The majority $(84.9 \%)$ of the population resides in rural areas, with agriculture being the major means of livelihood [25]. The zone is characterized by three agroecological settings, locally named, Dega ${ }^{1}$ (high altitude), Woina Dega ${ }^{2}$ (mid altitude), and Kolla (low altitude).

The study area, Sodo Gurage district (Fig. 1), is one of the thirteen districts and one of the two town administrations in Gurage zone. It is bordered to the south by the Meskan District, in the west by the Ezna Wolene

\footnotetext{
${ }^{1}$ Dega refers to a high-altitude (highland) agro-climatic region

${ }^{2}$ Woina dega denotes a mid-altitude (midland) agro-climatic region

${ }^{3}$ Kolla refers to a low altitude (lowland) agro-climatic region
} 


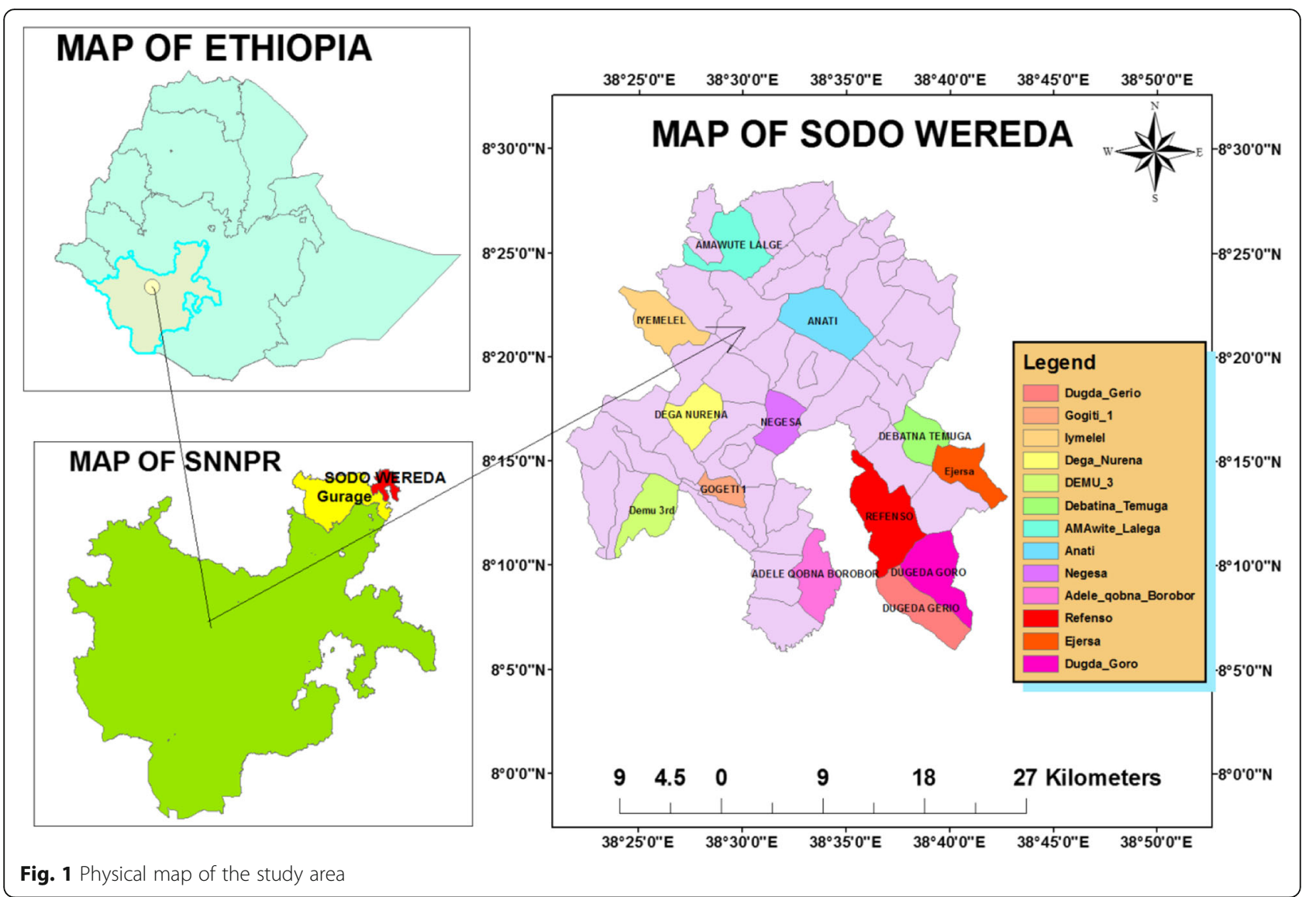

District, in the northwest by the Gedebano Gutazer district, in the southeast by the Mareko district and in the north by the Oromia Regional State. The Sodo district is located to the south of the Ethiopian capital, Addis Ababa, at a distance of $94 \mathrm{~km}$, and northwest of the regional capital, Hawassa, at a distance of $200 \mathrm{~km}$. It receives an average annual rainfall of 801-1200 mm, which is a mono-modal intensity. The mean annual temperature ranges from 12.6 to $20{ }^{\circ} \mathrm{C}$. Mixed farming is the dominant livelihood in the area. The type of crops cultivated are predominantly wheat (Triticum aestivum), teff (Eragrostis tef), maize (Zea mays), barley (Hordeum vulgare), and sorghum (Sorghum bicolor). The total cattle population is about 348,295 . The district consists of 58 kebeles $^{4}$ (54 rural and 4 urban kebeles) [12]. The total population for the year 2016 was 169,094 (49.6\% male and $50.4 \%$ female) and about $83.6 \%$ of the population resides in rural areas [25]. The major daily energy supply is derived from traditional energy sources such as firewood and charcoal, and to some extent from kerosene and solar panels. Biogas also supplies energy for a large number of households.

${ }^{4}$ Kebele denotes the lowest administrative unit in the Ethiopian Administration System.

\section{Data source and sampling procedures}

This study is based on a cross-sectional survey that considered both primary and secondary data sources. The primary data were gathered from sample rural households through a semi-structured questionnaire. Semi-structured interview questionnaires were chosen because they could include quantitative and qualitative questions. The questionnaire was pretested before the collection of actual data to improve wording and avoid ambiguity. The secondary data were collected from different published and unpublished sources, including books, journal articles, office reports and records, magazines, and internet sources. The secondary data were used as a background information to triangulate statistical results and to support arguments. The data collected consisted of demographic, socioeconomic, biophysical, and institutional factors. The observation units were biogas adopter and nonadopter households. A simple random sample procedure was used to select biogas adopter households. More precisely, a lottery method was used for the random selection of biogas adopter households.

The general formula developed by Air University (AU) was used to determine the sample size of biogas adopter households [26]. Most studies apply a 95\% confidence 
level and a $\pm 5 \%$ precision level. Accordingly, the sample size was determined using the following formula:

$$
n=\frac{N Z^{2} p(1-p)}{d^{2}(N-1)+Z^{2} p(1-p)}
$$

where $n=$ sample size required, $N=$ total population size, $d=$ precision level (0.05), $Z=$ number of standard deviation units of the sampling distribution corresponding to the desired precision level (1.96), and $p=$ estimated population proportion $(0.5)$.

Thus, $n=\frac{206(1.96)^{2} * 0.25}{(0.05)^{2}(205)+(1.96)^{2} * .25}=\frac{197.8424}{1.4729} \approx 134$

To select sample non-adopter households, a purposive sampling technique was used. Non-adopters were selected from the total potential biogas adopter households. There were about 13,570 such households in the Sodo Gurage district [12]. Amongst the non-adopter households, only those who owned four or more heads of cattle were considered as potential biogas adopters [6]. Since there exists a strong social interaction in rural areas, the non-adopter households share information about biogas technology with the adopters. Hence, one nearest neighbor for each sample biogas adopter household was chosen purposefully out of the total potential biogas adopter households identified by the NBP. The purposive sampling technique was used since the relative sizes of biogas adopter households are quite disproportional to the sizes of potential biogas households across kebeles in the district. Thus, 268 sample households in total were considered in the study (Table 1). An equal sample size of biogas adopter and non-adopter households was used to ease the comparison [27].

\section{Method of data analysis and model specification}

The data were presented and analyzed by means of statistical techniques, principally descriptive statistics, such as mean values and percentages, as well as a binary logistic regression model using STATA software package version 13. An independent sample $t$ test and chi-square test were used to compare the difference between the mean values of the explanatory variables of the biogas adopter and non-adopter households to determine whether the difference was significant or not. Moreover, a logistic regression model was applied to determine the underlying factors influencing the adoption of biogas technology.

The logistic regression model is a probability estimation model applied when the dependent variable is binary and the independent variable is measurement scalevariable [28]. Technology adoption is a binary decision on whether to have or not to have the technology, which in the current study is to have a bio-digester installation or not. Thus, a household is labeled as a biogas technology adopter if it has a bio-digester installation and nonadopter if it does not have a bio-digester installation for a biogas technology adoption. The following assumption was used:

$Y_{i}=1$ if a household i owns a bio-digester

$Y_{i}=0$ otherwise

where $Y$ denotes the dependent variable, that is, biogas technology adoption and $Y$ takes a value of either 1 or 0 .

Table 1 Sample size and proportional distribution across study kebeles

\begin{tabular}{|c|c|c|c|c|c|c|c|c|}
\hline \multirow[t]{3}{*}{$\begin{array}{l}\text { S. } \\
\text { no }\end{array}$} & \multirow[t]{3}{*}{$\begin{array}{l}\text { Name of } \\
\text { Kebele }\end{array}$} & \multicolumn{3}{|c|}{ Adopter households } & \multicolumn{3}{|c|}{$\begin{array}{l}\text { Non-adopter } \\
\text { households }\end{array}$} & \multirow{3}{*}{$\begin{array}{l}\text { Total } \\
\text { sample } \\
\text { households }\end{array}$} \\
\hline & & \multirow[t]{2}{*}{ Total } & \multicolumn{2}{|c|}{ Sample selected } & \multirow[t]{2}{*}{ Total } & \multicolumn{2}{|c|}{ Sample selected } & \\
\hline & & & Number & Percent & & Number & Percent & \\
\hline 1 & Dugda Goro & 21 & 14 & 10.4 & 1450 & 14 & 10.4 & 28 \\
\hline 2 & Ejersa & 40 & 26 & 19.4 & 2635 & 26 & 19.4 & 52 \\
\hline 3 & Refenso & 30 & 20 & 14.9 & 1976 & 20 & 14.9 & 40 \\
\hline 4 & Borobore & 10 & 6 & 4.5 & 659 & 6 & 4.5 & 12 \\
\hline 5 & Kersa & 15 & 11 & 8.2 & 1115 & 11 & 8.2 & 22 \\
\hline 6 & Anate & 9 & 6 & 4.5 & 690 & 6 & 4.5 & 12 \\
\hline 7 & Tumuga & 15 & 10 & 7.5 & 750 & 10 & 7.5 & 20 \\
\hline 8 & Damu-3 & 10 & 6 & 4.5 & 650 & 6 & 4.5 & 12 \\
\hline 9 & Dega Nurena & 11 & 7 & 5.2 & 600 & 7 & 5.2 & 14 \\
\hline 10 & Aymelel & 13 & 8 & 5.95 & 750 & 8 & 5.95 & 16 \\
\hline 11 & Negesa & 10 & 6 & 4.5 & 545 & 6 & 4.5 & 12 \\
\hline 12 & Gogeti & 12 & 8 & 5.95 & 1100 & 8 & 5.95 & 16 \\
\hline 13 & Gereye & 10 & 6 & 4.5 & 650 & 6 & 4.5 & 12 \\
\hline \multicolumn{2}{|c|}{ Grand total } & 206 & 134 & 100 & 13,570 & 134 & 100 & 268 \\
\hline
\end{tabular}


Variables explaining adoption of biogas technology

Explanatory variables considered in the adoption process have often lacked a firm theoretical basis, possibly because households consider different issues beyond socioeconomic incentives, including noneconomic factors. Adoption in this study was considered as the installation of a family-sized bio-digester and use of biogas for various purposes. In this study, demographic, socioeconomic, and institutional characters were expected to be the key factors determining the household's decision to adopt biogas technology. Previous studies $[4,15-17,29,30]$ have indicated socioeconomic, demographic, biophysical, and institutional factors as key determinants of biogas technology adoption. Accordingly, a full list of selected explanatory variables as well as their descriptions and presumed influences on the adoption of biogas technology is presented in Table 2 .

\section{Gender}

Since women dominate rural household energy consumption, it can be expected that households headed by women could have a higher probability of adopting biogas technology than their male counterparts [29, 31]. However, in Ethiopia, men dominantly control and make decisions regarding household resources [32], have more access and ownerships to resources and could, therefore, directly influence decisions in biogas technology adoption. Hence, in this study, the gender of a household head was expected to have either a positive or a negative effect on biogas technology adoption.

\section{Age}

Older household heads could have a greater economic capacity to afford investments in adopting biogas technology. On the contrary, older household heads are less flexible and less likely to accept new technologies. Because older household heads might be more risk-averse than younger ones and have a lower likelihood of adopting new technology $[33,34]$, in this study, the age of the household head was expected to have a positive or a negative influence on the decision to adopt biogas technology.

\section{Education}

Household heads with higher education levels were found to be more flexible, more informed, more knowledgeable, and more aware of environmental health as a result of the use of cleaner energy sources [16]. Thus, in this study, the number of years of education of a household head was expected to have a positive influence on the adoption of biogas technology.

\section{Household size}

Larger household size may mean a larger number of workers and, thus, more laborers for daily biogas operation activities [16, 17, 21]. Thus, household size was

Table 2 Definition of explanatory variables supposed to determine the adoption of biogas technology, and their presumed signs in association with dependent variables

\begin{tabular}{|c|c|c|c|}
\hline Variable & Type & Description & Expected sign \\
\hline Sex (Sexhhh) & Categorical & Sex of household head: male $=1$; female $=0$ & \pm \\
\hline Age (Agehhh) & Continuous & Age of the household head in years & \pm \\
\hline Education (Educhhh) & Continuous & Household head's educational level in years of schooling & + \\
\hline Household size (Sizehh) & Continuous & Total number of people in the household & \pm \\
\hline Head of cattle (Catthds) & Continuous & Household's total number of cattle in cow equivalent ${ }^{a}$ & + \\
\hline Total income (Tincomhh) & Continuous & Total annual income of the household in Birr ${ }^{b}$ & + \\
\hline Access to credit (Accredit) & Categorical & Having access to credit $=1$; otherwise $=0$ & + \\
\hline Farmland size (Sizfarmh) & Continuous & Household's total farmland owned in hectare (ha) & + \\
\hline Number of planted Trees (Numplant) & Continuous & Household's total number of planted trees & \pm \\
\hline Distance to firewood source (Distwood) & Continuous & Walking distance of the major fuelwood source from home (min) & + \\
\hline Distance to water source (Distwatr) & Continuous & Walking distance to the major water source from home (min) & - \\
\hline Adequacy of available water (Suffwatr) & Categorical & Having adequate water source $=1$; otherwise $=0$ & + \\
\hline Distance to market (Distmrkt) & Continuous & Walking distance of the market from home (min) & - \\
\hline Perception to use \& mgt (Indivperc) & Categorical & Having perception resisting biogas technology $=1$; otherwise $=0$ & - \\
\hline Access to electricity (Accelect) & Categorical & Having electricity connection $=1$; otherwise $=0$ & - \\
\hline Electronic media (Elemedia) & Categorical & Having radio and/or television $=1$; otherwise $=0$ & + \\
\hline
\end{tabular}

${ }^{\mathrm{a}}$ Head of cattle ownership was measured in cow equivalent where, cow $=1$; ox $=1.25$ cow equivalent; bull = 1.25 cow equivalent; immature male $=0.75$ cow equivalent; heifer $=0.63$ cow equivalent; and calf $=0.25$ cow equivalent [20].

${ }^{\mathrm{b}}$ Birr is a basic monetary unit in Ethiopia (1 USD is equivalent to 23.37 Ethiopian Birr in May 2017) 
hypothesized to influence adoption of biogas technology either positively or negatively.

\section{Size of the cattle herd}

The size of cattle herds owned by a household is a key factor in biogas technology adoption, as cattle provide cow dung, which is the major input from operating family-size bio-digesters in Ethiopia. The size of cattle herd owned by a household is a prerequisite for biodigester installation as it indicates the amount of available feedstock for bio-digester operation in Ethiopia [6]. Thus, the number of cattle, provided with cow equivalent, was hypothesized to have a positive influence on the adoption of biogas technology.

\section{Total income}

Technology adoption is influenced by household income. Households with a higher income level are more likely to adopt biogas technology than their counterparts. Thus, household income was hypothesized to positively influence biogas technology adoption.

\section{Access to credit}

In Ethiopia, the initial investment for bio-digester installation is unaffordable for a considerable number of rural households [35]. Thus, households' access to credit was expected to positively influence biogas technology adoption.

\section{Farm size}

For a biogas unit to run effectively and efficiently, all three components, namely, bio-digester, animal unit and feedstock, need to be close to each other for easy provision of feedstock to the bio-digester and effective monitoring of routine operation and maintenance activities [16]. Thus, farm size owned by a household was expected to have a positive influence on biogas technology adoption.

\section{Number of planted trees}

In Ethiopia, firewood is the major source of domestic energy consumption in rural areas. The major sources of firewood are either natural forests or artificial tree plantations. Having a high number of planted trees may mean facilitated access to household energy and, hence, less incentive to adopt biogas technology. On the contrary, having a higher number of planted trees may mean having better cash to be able to finance biogas installation. Thus, the number of planted trees was supposed to have either a positive or negative influence on the adoption of biogas technology.

\section{Distance to firewood source}

When the distance between firewood sources and home increases, the opportunity cost for collecting firewood, spending a significant share of their time and labor on firewood collection also rises $[3,4,14]$. Thus, the distance between the major firewood sources and the residence was supposed to have a negative influence on the adoption of biogas technology.

\section{Distance to water sources}

As the sources of water near the residence increase, households' inspiration to install bio-digesters decreases. For routine feedstock preparation of bio-digesters, the sources of water were recommended to be within a walking distance of 20-30 min from the residence [6, 19]. Thus, a long distance between water sources and the residence was supposed to have a negative influence on biogas technology adoption.

\section{Adequacy of available water}

An adequate water supply is a key factor and a prerequisite for a bio-digester installation as well as for sustainable bio-digester operation. Consequently, it influences the decision of biogas technology adoption [6]. Thus, the availability of an adequate water supply was supposed to have a positive influence on biogas technology adoption.

\section{Distance to market places}

Distance from residence to market places for purchasing spare parts was hypothesized to negatively influence the adoption of biogas technology. Therefore, closer market places were expected to help households get easier access to buy spare parts that are accompanied by positive influence on biogas technology adoption.

\section{Perception of the use and management of biogas and bio- slurries}

In some communities in Africa, it is socially unacceptable to install biogas technologies, as they involve a collection of cow dung and human excreta, which are perceived as disgusting waste [1]. Thus, such resistant perception of households to use toilets for biogas energy generation and management and to use bio-slurries for fertilizer was supposed to have a negative influence on biogas technology adoption.

\section{Access to electricity}

Access to electricity was expected to have a negative influence on the adoption of biogas technology. Once installed, an electricity connection does not require routine labor and other costs. The spare parts are also cheaper and more accessible compared to those of biodigesters. 


\section{Access to electronic media}

Having electronic media such as radio and television was expected to increase households' awareness with regard to the benefit and management of biogas technology and thus was expected to have a positive influence on households' biogas technology adoption.

\section{Results and discussion}

\section{Profile of sample households}

The mean and percentage values of the variables predicted to determine a household's decision to adopt biogas technology are computed and listed in Table 3. The analysis showed that out of the sampled 268 households, about $81 \%$ were male-headed. On average, the adopter households are characterized by a higher level of education, a larger farm and cattle size, a higher annual income, and more planted trees. In fact, they were far away from firewood sources, but closer to water sources and market places. They had better access to credit services and adequate water sources. Moreover, adopter households had a better perception of the use of toilets for biogas energy and bio-slurry utilization. Likewise, they had better access to electronic media, but limited access to electricity.

The annual income and farm size of adopter households were approximately twice higher than those of their counterparts. The average distance to firewood sources, water sources, and the nearest market for the adopter and non-adopter households was 57 and 35, 26 and 47, and 46 and 64 minutes, respectively. This shows that adopter households had better access to water sources for adequate water supply and to market places for purchasing spare parts. In contrast, such households had limited access to firewood sources compared to their counterparts. Adopter households' access to credit services and adequate water supply were exceedingly higher than that of non-adopter households.

The significant mean differences in education level, cattle size, household income, farm size, number of planted trees, distance to water sources, distance to firewood sources, and distance to the nearest market between biogas adopter and non-adopter households (Table 3) were mostly corresponding with previous findings [20] in Ethiopia. In addition, Abadi et al. [35] indicated that the mean walking distance to the nearest forest for firewood was significantly higher for biogas adopters than that for non-adopters. Adopter households were more prestigious than their counterparts in terms of socioeconomic and demographic characteristics (Table 3). The results from previous research studies in Ethiopia [20,36, 37] and in many other African countries $[1,14,16]$ supported this finding. Furthermore, the probability of a household adopting biogas technology increases with increasing household income, number of cattle owned, and household size as well as being a male-headed household in Uganda. In contrast, the likelihood of biogas technology adoption decreases with increasing remoteness of household location [16]. Similarly, the mean difference between biogas adopters and non-adopters was significant in terms of the gender of the household head, access to credit, access to an adequate water source, perception to the use of toilets for biogas and bio-slurries, and access to electricity and electronic media (Table 3). For adopter households, the average walking distance to water sources, firewood sources and market places were 26,57 , and $46 \mathrm{~min}$, respectively. The distance to the firewood source is far beyond the NBP assumption (30 min) whereas the distance to water sources is within the NBP assumption (30 min). The average cattle size for adopter households was nine, which is well above the NBP's recommendation (four heads of cattle). This shows that cattle size and the walking distances to firewood and water sources mostly conform to the NBP's recommendations [6]. However, the mean difference in the age of household heads and the size of households between adopter and non-adopter households were insignificant (Table 3), which is consistent with previous findings by Walekhwa et al. [16] in Uganda, and by Mendola [38] and Kabir et al. [17] in Bangladesh.

\section{Factors influencing biogas technology adoption}

The estimated results of the binary logistic regression model indicated that the estimated values fit the observed data reasonably well. The LR $\chi^{2}$ test was based on the assumption that at least one of the coefficients of the regression predictor was not equal to zero. The estimated LR $\chi^{2}$ test value was 229.85 , which indicated that the predictors' coefficients were different from 0 . Furthermore, the complete model comprising the full number of predictors was found to be highly significant $\left(\right.$ Prob $\left.>X^{2}(\mathrm{DF}=15)=250.57, p=0.000\right)$, with a high Pseudo $R^{2}$ value (62\%). Measures of goodness-of-fit of the model results indicated that the independent variables were simultaneously related to the log odds of adoption. Moreover, the chosen independent variables correctly predicted households' biogas adoption conditions for the entire observed data.

Table 4 depicts the binary logistic regression results, which help to identify the determinants of biogas technology adoption. Among the 15 explanatory variables identified, 7 variables had a significant influence on the household's decision to adopt biogas technology. Educational level and access to electronic media were significant variables in influencing the decision to adopt biogas technology $(p<0.1)$. Total annual income and access to credit were significant variables $(p<0.01)$ and distance to firewood sources, distance to water sources and 
Table 3 Descriptive statistics for variables explaining the adoption of biogas technology

\begin{tabular}{|c|c|c|c|}
\hline Variable & Adopter $(N=134)$ & Non-adopter $(N=134)$ & $t$ value \\
\hline Age of household head & 45.9 & 47.4 & 1.10 \\
\hline Education level & 6 & 3.9 & $-5.06^{* *}$ \\
\hline Size of household & 6 & 6.08 & 0.36 \\
\hline Cattle heads & 9.23 & 7.75 & $-3.36^{* *}$ \\
\hline Total annual income & 81587.54 & 31819.10 & $-10.66^{* *}$ \\
\hline Size of farmland & 1.25 & 0.98 & $-4.53^{* *}$ \\
\hline Number of planted trees & 723.7 & 193.0 & $-2.41^{*}$ \\
\hline Distance to fuelwood source & 56.58 & 35.16 & $-5.68^{* *}$ \\
\hline Distance to water source & 26.34 & 46.50 & $6.12^{* *}$ \\
\hline \multirow[t]{2}{*}{ Distance to the nearest market } & 46.34 & 63.99 & $55.17^{*}$ \\
\hline & & & $x^{2}$ value \\
\hline \multicolumn{4}{|l|}{ Sex of household head (\%) } \\
\hline Female & 12.7 & 24.6 & \\
\hline Male(1) & 87.3 & 75.4 & $6.29^{*}$ \\
\hline \multicolumn{4}{|l|}{ Access to credit (\%) } \\
\hline Otherwise & 3.0 & 70.1 & $130.30^{* *}$ \\
\hline Having access to credit (1) & 97.0 & 29.9 & \\
\hline \multicolumn{4}{|l|}{ Adequacy of water source (\%) } \\
\hline Otherwise & 50.7 & 90.3 & $50.42^{* *}$ \\
\hline Have adequate water (1) & 49.3 & 9.7 & \\
\hline Perception to use and management (\%) & 91.0 & 77.6 & $9.15^{* *}$ \\
\hline Otherwise & 9.0 & 22.4 & \\
\hline \multicolumn{4}{|l|}{ Resistant perception (1) } \\
\hline \multicolumn{4}{|l|}{ Access to electricity (\%) } \\
\hline Otherwise & 97.8 & 89.6 & $7.60^{* *}$ \\
\hline Access to electricity (1) & 2.2 & 10.4 & \\
\hline \multicolumn{4}{|l|}{ Electronic media (\%) } \\
\hline Otherwise & 4.5 & 17.2 & $11.17^{* *}$ \\
\hline Having electronic media (1) & 95.5 & 82.8 & \\
\hline
\end{tabular}

Note: ** and * represent statistically significant mean differences between biogas users and non-users at $p<0.01$ and $p<0.05$, respectively

access to electricity did also significantly $(p<0.05)$ influence the decision to adopt biogas technology. The influence of these variables on the household's decision to adopt biogas technology is consistent with previous findings [3, 36, 39] in Ethiopia [17], Bangladesh, and Uganda [16]. Most of these factors affected households' decisions to adopt biogas technology in Africa [1, 14, 30]. More importantly, these results show that households' socioeconomic characteristics are key determinants in decision-making to adopt or not to adopt biogas technology.

\section{Educational level}

The results of the logistic regression analysis indicated a significant $(p<0.1)$ positive association between the educational level of household heads and the decision of adopting biogas technology (Table 4). Accordingly, the likelihood of biogas technology adoption increases by a factor of 1.14 with a one-year increase in the educational level of household heads. Moreover, there was a significant $(p<0.01)$ mean difference of the education level between adopter and non-adopter households of biogas technology (Table 4). Household heads with a higher education level had better ability to adopt a technology than their counterparts $[40,41]$. Years of education of the household head had likewise a significant positive association with biogas technology adoption in Ethiopia [39], Kenya [15], and Bangladesh [17]. This might be due to the fact that households with no or low formal education are more likely to be skeptical to take up a new technology than are their counterparts. Such households are commonly reluctant to learn and acquire new knowledge, 
Table 4 Binary logistic regression model results for the factors affecting biogas technology adoption $\left(Y_{i}\right)$

\begin{tabular}{lllll}
\hline Adoption $\left(\mathrm{Y}_{\mathrm{i}}\right)$ & Odds ratio & Standard error & $Z$ value & $P$ value \\
\hline _cons & 0.0013 & 1.7588 & -3.19 & 0.000 \\
Sexhhh $($ male = 1) & 1.0336 & 0.6422 & 0.05 & 0.959 \\
Educhhh & 1.1404 & 0.0741 & 1.77 & 0.076 \\
Sizehh & 0.9844 & 0.1250 & -0.13 & 0.900 \\
Catthds & 0.9748 & 0.0711 & -0.36 & 0.720 \\
Tincomhh & 1.00004 & 0.00001 & 4.73 & 0.000 \\
Accredit $($ yes = 1) & 31.7334 & 0.6644 & 5.20 & 0.000 \\
Sizfarmh & 1.7688 & 0.6206 & 0.92 & 0.358 \\
Numplant & 1.0002 & 0.0003 & 0.54 & 0.592 \\
Distwood & 1.0177 & 0.0071 & 2.49 & 0.013 \\
Distwtr & 0.9706 & 0.0142 & -2.10 & 0.036 \\
Suffwtr (yes $=1)$ & 0.7797 & 0.6630 & -0.38 & 0.707 \\
Distmrkt & 1.0034 & 0.0075 & 0.46 & 0.648 \\
Indivperc $($ no $=1)$ & 0.6476 & 0.6632 & -0.66 & 0.512 \\
Accelect $(y e s=1)$ & 0.0466 & 1.1906 & -2.58 & 0.010 \\
Elemedia $(y e s=1)$ & 5.4427 & 0.8989 & 1.88 & 0.059 \\
\hline
\end{tabular}

hence uninterested in adopting new technologies. Contextually, this shows that an increase in an educational level might perhaps increase the ability of households to use available information in decision-making to adopt biogas technology. Moreover, education is more likely to ensure a better understanding of indirect benefits associated with biogas technology, such as for example improvement in health, improved bio-slurries used for fertilization and, finally yet importantly, reduced workload for cooking and firewood collection, which are usually tasks are done by women and children.

\section{Total annual household income}

There was a significant $(p<0.01)$ positive association between total annual household income and biogas technology adoption. Accordingly, an increase in household income level by 1.0 ETB was found to increase the probability of biogas technology adoption by a factor of 1.0001 , ceteris paribus (Table 4). This finding is consistent with the findings of Mwirigi et al. [15] that a household income level has a positive influence on the household's decision of biogas technology adoption in Kenya. A similar finding was reported by Kabir et al. [17] in Bangladesh and Walekhwa et al. [16] in Uganda. More annual income might provide more economic capacity and legibility for a bio-digester installation and affordability of buying spare parts for maintaining an installed biogas digester operational. More annual income perhaps would also mean a higher probability of receiving credit or loan from credit associations and local moneylenders.

\section{Access to credit}

Access to credit had significantly $(p<0.01)$ and positively influenced biogas technology adoption (Table 4). Having access to credit by households increased the likelihood of biogas technology adoption by a factor of 31.73 compared to their counterparts. Thus, access to credit is a key factor in enhancing the poor households' affordability of biogas technology adoption. These findings are supported by previous studies conducted in Ethiopia by Mengistu et al. [20] and Berhe et al. [21], which described the existence of a significant positive relationship between access to credit and biogas technology adoption. Both studies stated that the availability of credit services in rural areas is likely to ease the financial constraints for managing bio-digesters. Likewise, the findings from this study are consistent with those of Parawira [14], who stated that credit services and easing financial constraints could promote the management of biogas technology in sub-Saharan African countries. Therefore, access to credit services is an important variable in biogas technology adoption, particularly through motivating households to adopt technology, increase the financial capacity of households' bio-digester installation and enable faster maintenance services.

\section{Distance to firewood sources}

There was a significant $(p<0.05)$ and a positive association between the distance to firewood sources and biogas technology adoption (Table 4). As the distance to firewood sources from the residence increased by $1 \mathrm{~min}$, the likelihood of households' to adopt biogas technology increased by a factor of 1.02 . Similar findings have been reported $[3,20]$ for Ethiopia and $[4,14,16]$ other African countries. When the source of firewood is far from the residence, household members spend a significant share of their time and labor on firewood collection that would in turn affect the opportunity for pursuing other agricultural activities. More importantly, since the source of firewood has been declining rapidly in recent times, those households envisage biogas technology as an alternative source of energy.

\section{Distance to water sources}

As hypothesized, there was a significant $(p<0.05)$ negative association between the distance from the residence to water sources and the adoption of biogas technology (Table 4). When the distance to water sources from the residence increased by $1 \mathrm{~min}$, the likelihood of households to adopt biogas technology decreased by a factor of 0.97 . This implies that the distance to water sources is a determinant factor for the adoption of biogas technology. This finding is supported by a study conducted by Abadi et al. [36], who showed a significant negative association between the distance to the nearest water sources 
and biogas technology adoption in northern Ethiopia. Access to water is mandatory for biogas production and, hence, biogas technology adoption [4]. To avoid a shortage of water, most adopters connected their toilets to the biogas digesters, which is also supported by an earlier finding in northern Ethiopia [39].

\section{Access to electricity}

Access to electricity had a significantly $(p<0.05)$ negative influence on the adoption of biogas technology (Table 4). Households' access to electricity decreased the probability of adopting biogas technology by a factor of 0.047 compared to households lacking access to electricity. As opposed to this finding, in a previous study by Kelebe et al. [39] in northern Ethiopia a positive relationship between access to electricity and the adoption of biogas technology was ascertained. However, rural households with, perhaps, access to electricity prefer electricity to the biogas technology for its lower cost for connection, maintenance and purchasing of spare parts. In contrast, bio-digester operation requires routine physical work for dung collection, fetching water, feedstock preparation, and bio-digester feeding. Yet, households with access to electricity use it only for lighting and not even for cooking. National governments usually domesticate biogas technology for its multiple benefits, namely, for cooking food, boiling water, lighting, and bio-slurries as organic fertilizers, among others. In this regard, biogas technology is more useful than having electricity access for subsistent rural households in developing countries.

\section{Access to electronic media}

There was a significantly $(p<0.1)$ positive association between access to electronic media (Table 4), like radio and/or television, and the household decision to adopt biogas technology. Ceteris paribus, having access to electronic media increases the likelihood of adopting biogas technology by a factor of 5.44 as compared to their counterparts. This means that households with access to electronic media would have better access to information and awareness in terms of biogas technology. In this regard, there are national and regional radio programs, which broadcast information on biogas technology. Thus, this finding is supported by a previous work [42] that technology adoption is higher among individuals having information and awareness through different communication means than their counterparts. There are also similar reports in northern Ethiopia [36, 38].

\section{Triangulating with qualitative information}

The key informants reported that there exists a lack of skilled workmanship in the biogas sector and poor promotion activities. Focus group discussants also confirmed the presence of non-functioning and poorly functioning bio-digesters of those adopting households, lack of adopters' skill to operate and maintain bio-digesters, and shortage of water supply. These challenges have constrained the proper functioning of bio-digesters, and because of this, some non-adopters in the study, have resisted adopting the biogas technology.

Both focus group discussants and key informants also reported on problems associated with poor quality construction materials for bio-digester installation, nonoperating biogas stoves as well as lumps, and poor maintenance services. The above-mentioned problems and abandonment of non-functioning bio-digesters have contributed to the low adoption of biogas technology and a return to the use of traditional biomass energy systems [7, 20, 37, 39].

\section{Conclusion and recommendation}

Biogas technology mostly appears in privileged households with better socioeconomic status and other resource endowments. The beneficiaries are that households are able to afford higher initial investment costs for bio-digester installation, maintenance services, and purchasing bio-digester spare parts in case they have access to credit facilities, water sources for adequate water supply, markets for purchasing spare parts and electronic media for information, and are residing far away from firewood sources. Toilets complement cow dung and water for feedstock preparation in a considerable number of households to ensure an adequate supply of feedstock. Nonetheless, financial constraints, lack of biophysical resources, and lack of smooth and untimely loan disbursements are major determinants limiting the number of households adopting biogas technology. Thus, to overcome the multifaceted obstacles of the adoption of biogas technology, there is a need for an outstanding re-consideration and a firm commitment at all levels (government and non-government organizations, energy experts, private enterprises, research institutes, farmers) to enhance a household's decision to adopt biogas technology and enjoy the multiple benefits of the technology. Stakeholder institutions should arrange smooth and reasonable credit sizes for all potential adopters to enhance households' decisions to adopt biogas technology. Furthermore, efforts towards improving the education level of household heads and the respective promotion exercises should be strengthened to ensure access to sustainable water sources to motivate households to adopt biogas technology. These findings might also be useful to strengthen the national biogas energy programs, which are being particularly popularized and employed in several Asian and Sub-Sahara African countries. 


\section{Acknowledgements}

We would like to thank NORHED-EnPe, a collaborative project between Hawassa University, Mekelle University, and Norwegian University of Life Sciences, NMBU, for providing financial support. We owe due appreciation to all respondent households, group discussants, and key informants who provided invaluable information. We also offer due respect to all organizations and their staff for providing invaluable data. Particularly, we would like to thank the following organizations: South Region Biogas Program Coordination Unit, Sodo District Energy and Mines Office, Sodo District Agriculture and Rural Development Office, Sodo District Administration Office, and Kebele Administrations.

\section{Authors' contribution}

All authors were involved in data collection and writing of the manuscript. All authors read and approved the final manuscript for submission and publication.

\section{Funding}

Not applicable

\section{Availability of data and materials}

Not applicable

\section{Ethics approval and consent to participate}

Not applicable

\section{Consent for publication}

Not applicable

\section{Competing interests}

The authors declare that they have no competing interests.

\section{Author details}

'Department of Economics, College of Business and Economics, Wolkite University, PO Box 07, Wolkite, Ethiopia. 'Department of Economics, College of Business and Economics, Hawassa University, Hawassa, Ethiopia. ${ }^{3}$ Department of Biology, College of Natural Sciences, Hawassa University, PO Box 05, Hawassa, Ethiopia. ${ }^{4}$ Department of Plant Sciences (IPV), Norwegian University of Life Sciences (NMBU), Ås, Norway.

\section{Received: 26 September 2018 Accepted: 13 December 2019}

\section{Published online: 06 January 2020}

\section{References}

1. Amigun, B., Parawira, W., Musango, J., Aboyade, A. \& Badmos, A. (2012). Anaerobic biogas generation for rural area energy provision in Africa. In Biogas: InTech.

2. Amare ZY (2015) The benefits of the use of biogas energy in rural areas in Ethiopia: A case study from the Amhara National Regional State, Fogera District. African J Environ Sci Technol 9(4):1-14

3. Guta DD (2012) Assessment of biomass fuel resource potential and utilization in Ethiopia: sourcing strategies for renewable energies. Int $J$ Renew Energy Res (IJRER) 2(1):131-139

4. Mwirigi J, Balana BB, Mugisha J, Walekhwa P, Melamu R, Nakami S, Makenzi P (2014) Socio-economic hurdles to widespread adoption of small-scale biogas digesters in Sub-Saharan Africa: A review. Biomass Bioenergy 70:17-25

5. Rajendran K, Aslanzadeh S, Taherzadeh M (2012) Household Biogas Digesters - A Review. Energies 5:2911-2942

6. EREDPC \& SNV (2008) Ethiopian Rural Energy Development and Promotion Center (EREDPC) and Netherlands Development Organization (SNV). National Biogas Pro-gramme Ethiopia: Programme Implementation Document. EREDPC and SNV, Addis Ababa

7. Shallo L, Sime G (2018) Determinants of functional status of family size biodigesters: empirical evidence from southern Ethiopia. Int J Sustain Energy. https://doi.org/10.1080/14786451.2018.1538145

8. Rogers EM (1983) Diffusion of Innovations. The Free press, New York

9. Glivin G, Sekhar S (2016) Experimental and Analytical Studies on the Utilization of Biowastes Available in an Educational Institution in India. Sustainability 8(11):1128
10. Bi SJ, Hong XJ, Wang GX, Li Y, Gao YM, Yan L, Wang YJ, Wang WD (2016) Effect of domestication on microorganism diversity and anaerobic digestion of food waste. Genetics Mol Res 15(3):1-14

11. Kamp, L. M. \& FORN, E. B. (2015).Bottlenecks and drivers in Ethiopia domestic biogas sector. IAMOT.

12. RBPCU (2016).Annual Report for the Year 2015 : Regional Biogas Programme Coordination Unit (RBPCU): SNNPR Mines and Energy Agency. Hawassa, Ethiopia.

13. Ghimire PC (2013) SNV supported domestic biogas programmes in Asia and Africa. Renewable Energy 49(Supplement C):90-94

14. Parawira W (2009) Biogas technology in sub-Saharan Africa: status, prospects and constraints. Rev Environ Sci Bio/Technology 8(2):187-200

15. Mwirigi JW, Makenzi PM, Ochola WO (2009) Socio-economic constraints to adoption and sustainability of biogas technology by farmers in Nakuru Districts, Kenya. Energy Sustain Dev 13(2):106-115

16. Walekhwa PN, Mugisha J, Drake L (2009) Biogas energy from family-sized digesters in Uganda: Critical factors and policy implications. Energy Policy 37(7):2754-2762

17. Kabir H, Yegbemey RN, Bauer S (2013) Factors determinant of biogas adoption in Bangladesh. Renew Sustain Energy Rev 28(Supplement C):881-889

18. Qu W, Tu Q, Bluemling B (2013) Which factors are effective for farmers' biogas use?-Evidence from a large-scale survey in China. Energy Policy 63:26-33

19. Eshete $\mathrm{G}$, Sonder $\mathrm{K}$, Heegde $\mathrm{Ft}$ (2006) Report on the feasibility study of a national programme for domestic biogas in Ethiopia. SNV Netherlands Development Organization, Addis Ababa, Ethiopia

20. Mengistu M, Simane B, Eshete G, Workneh T (2016) Factors affecting households' decisions in biogas technology adoption, the case of Ofla and Mecha Districts, northern Ethiopia. Renewable Energy 93:215-227

21. Berhe TG, Tesfahuney RG, Desta GA, Mekonnen LS (2017) Biogas Plant Distribution for Rural Household Sustainable Energy Supply in Africa. Energy Policy Res 4(1):10-20

22. Lee L (2013) Household energy mix in Uganda. Energy Econ 39:252-261

23. Van Beukering P, Bruggink J, Brouwer R, Berkhout F, S. R. (2009) Greening the African energy ladder. In: The role of national policies and international aid. Institute for Environmental Studies. Vrirje Universiteit, Amsterdam

24. Mekonnen A, Köhlin G (2009) Determinants of household fuel choice in major cities in Ethiopia. In: Working Papers in Economics (399). University of Gothenburg, Sweden

25. CSA (2013).Population projection of Ethiopia for all regions at district level ( 2014-2017). Central Statistics Agency (CSA), Addis Ababa, Ethiopia.

26. AU (2002).Sampling and Surveying Handbook: Guidelines for Planning, Organizing and Conducting Survey, Air University (AU), http://www.au.af. mil/au/awc/awcgate/edref/smpl-srv.pdf. Accessed 10 Feb 2017.

27. Anderson S, Auquler A, Hauck WW, Oakes D, Vandaele W, Weisberg HI (1980) Statistical Methods for Comparative Studies: Techniques for Bias Reduction. Wiley, New York

28. Verbeek M (2004) A Guide to Modern Econometrics. Wiley, England

29. Amigun B, Sigamoney R, von Blottnitz H (2008) Commercialisation of biofuel industry in Africa: a review. Renew Sustain Energy Rev 12(3):690-711

30. Amigun B, Von Blottnitz H (2010) Capacity-cost and location-cost analyses for biogas plants in Africa. Resour Conserv Recycling 55(1):63-73

31. Karekezi S (2002) RenewablesinAfrica - meeting theenergyneedsofthepoor. Energy Policy 30:1059-1069

32. Lim SS, Winter-Nelson A, Arends-Kuenning M (2007) Household bargaining power and agricultural supply response: evidence from Ethiopian coffee growers. World Dev 35(7):1204-1220

33. Adesina AA, Baidu-Forson J (1995) Farmers' perceptions and adoption of new agricultural technology: evidence from analysis in Burkina Faso and Guinea, West Africa. Agric Econ 13(1):1-9

34. Bekele W, Drake $L$ (2003) Soil and water conservation decision behavior of subsistence farmers in the Eastern Highlands of Ethiopia: a case study of the Hunde-Lafto area. Ecol Econ 46(3):437-451

35. SNV (2017).Biogas production and utilization in Ethiopia - challenges and opportunities: Netherland Development Organization (SNV), Addis Ababa, Ethiopia.

36. Abadi N, Gebrehiwot K, Techane A, Nerea H (2017) Links between biogas technology adoption and health status of households in rural Tigray, Northern Ethiopia. Energy Policy 101:284-292

37. Kamp LM, Bermúdez Forn E (2016) Ethiopia's emerging domestic biogas sector: Current status, bottlenecks and drivers. Renew Sustain Energy Rev 60:475-488 
38. Mendola M (2007) Agricultural technology adoption and poverty reduction: a propensity-score matching analysis for rural Bangladesh. Food Policy 32(3): 372-393

39. Kelebe HE, Ayimut KM, Berhe GH, Hintsa K (2017) Determinants for adoption decision of small scale biogas technology by rural households in Tigray, Ethiopia. Energy Econ 66(Supplement C):272-278

40. Kabir Y, Zafar TA, Waslien C (2013) Relationship between perceived body image and recorded body mass index among Kuwaiti female university students. Women Health 53(7):693-705

41. Riddell, W. C. \& Song, X. (2012).The role of education in technology use and adoption: evidence from the Canadian workplace and employee survey. Institute for the Study of Labor. Discussion Paper No. 6377.

42. Wawa, A. I. (2012).The challenges of promoting and adopting biogas technology as alternative energy source in semi-arid areas of Tanzania: the case of Kongwa and Bahi Districts of Dodoma Region. ["eprint_fieldopt thesis_type_phd" not defined] thesis, THE OPEN UNIVERSITY OF TANZANIA.

\section{Publisher's Note}

Springer Nature remains neutral with regard to jurisdictional claims in published maps and institutional affiliations.

Ready to submit your research? Choose BMC and benefit from:

- fast, convenient online submission

- thorough peer review by experienced researchers in your field

- rapid publication on acceptance

- support for research data, including large and complex data types

- gold Open Access which fosters wider collaboration and increased citations

- maximum visibility for your research: over $100 \mathrm{M}$ website views per year

At BMC, research is always in progress.

Learn more biomedcentral.com/submissions 